\title{
Biosystematics studies on Elymus breviaristatus and Elymus sinosubmuticus (Poaceae: Triticeae)
}

\author{
LuTan', Qing-Xiang Huang ${ }^{1}$, Yang Song ${ }^{1}$, Dan-Dan Wu ${ }^{1,2}$, Yi-Ran Cheng ${ }^{1,2}$, Chang-Bin Zhang ${ }^{3}$, Li-Na Sha ${ }^{2,4}$, \\ Xing Fan ${ }^{1,2}$, Hou-Yang Kang ${ }^{1,2}$, Yi Wang ${ }^{1,2}$, Hai-Qin Zhang ${ }^{2,4^{*}}$ and Yong-Hong Zhou ${ }^{1,2^{*}}$
}

\begin{abstract}
Background: Elymus breviaristatus and Elymus sinosubmuticus are perennial herbs, not only morphologically similar but also sympatric distribution. The genome composition of E. sinosubmuticus has not been reported, and the relationship between E. sinosubmuticus and E. breviaristatus is still controversial. We performed artificial hybridization, genomic in situ hybridization, and phylogenetic analyses to clarify whether the two taxa were the same species.

Results: The high frequency bivalent (with an average of 20.62 bivalents per cell) at metaphase I of pollen mother cells of the artificial hybrids of E. breviaristatus $(\mathbf{S t Y H}) \times$ E. sinosubmuticus was observed. It illustrated that $E$. sinosubmuticus was closely related to $E$. breviaristatus. Based on genomic in situ hybridization results, we confirmed that $E$. sinosubmuticus was an allohexaploid, and the genomic constitution was StYH. Phylogenetic analysis results also supported that this species contained $\mathbf{S t}, \mathbf{Y}$, and $\mathbf{H}$ genomes. In their $\boldsymbol{F}_{1}$ hybrids, pollen activity was $53.90 \%$, and the seed setting rate was $22.46 \%$. Those indicated that the relationship between E. sinosubmuticus and E. breviaristatus is intersubspecific rather than interspecific, and it is reasonable to treated $E$. sinosubmuticus as the subspecies of $E$. breviaristatus.
\end{abstract}

Conclusions: In all, the genomic constitutions of E. sinosubmuticus and E. breviaristatus were $\mathbf{S t Y H}$, and they are species in the genus Campeiostachys. Because E. breviaristatus was treated as Campeistachys breviaristata, Elymus sinosubmuticus should be renamed Campeiostachys breviaristata (Keng) Y. H. Zhou, H. Q. Zhang et C. R. Yang subsp. sinosubmuticus (S. L. Chen) Y. H. Zhou, H. Q. Zhang et L. Tan.

Keywords: Campeiostachys, Chromosome pairing, Genomic in situ hybridization, Reproduction isolation, Biosystematics

\footnotetext{
*Correspondence: haiqinzhang@163.com; zhouyh@sicau.edu.cn ${ }^{1}$ Triticeae Research Institute, Sichuan Agricultural University, Wenjiang 611130, Chengdu, Sichuan, China

${ }^{2}$ State Key Laboratory of Crop Genetic Exploration and Utilization in Southwest China, Sichuan Agricultural University, Wenjiang 611130, Chengdu, Sichuan, China

Full list of author information is available at the end of the article
}

\begin{abstract}
Background
The tribe Triticeae includes about 450 species, of which about $75 \%$ are polyploid [1, 2]. Since Löve [1] proposed that the species with the same genome or same genome combinations were classified into one genus, about 30 genera were recognized by most of the grass scientists [3-9]. Elymus sensu lato (Elymus s.l.) is the largest genus of Triticeae, and it contains seven basic genomes: St, H, P, W, Ns, Y, and $\mathbf{X m}[3,8,10-12]$. St genome is from Pseudoroegneria (Nevski) Löve, $\mathbf{H}$ genome is from Hordeum L., P genome is from Agropyron Gartn.,
\end{abstract}

(C) The Author(s) 2022. Open Access This article is licensed under a Creative Commons Attribution 4.0 International License, which permits use, sharing, adaptation, distribution and reproduction in any medium or format, as long as you give appropriate credit to the original author(s) and the source, provide a link to the Creative Commons licence, and indicate if changes were made. The images or other third party material in this article are included in the article's Creative Commons licence, unless indicated otherwise in a credit line to the material. If material is not included in the article's Creative Commons licence and your intended use is not permitted by statutory regulation or exceeds the permitted use, you will need to obtain permission directly from the copyright holder. To view a copy of this licence, visit http://creativecommons.org/licenses/by/4.0/. The Creative Commons Public Domain Dedication waiver (http://creativeco mmons.org/publicdomain/zero/1.0/) applies to the data made available in this article, unless otherwise stated in a credit line to the data. 
W genome is from Australopyrum (Tzvelev) Löve, Ns genome is from Leymus Hochst. The origin of $\mathbf{Y}$ and $\mathbf{X} \mathbf{m}$ is still unknown $[3,7,9,13]$. Based on the genome combinations, Elymus s.l. was further divided into ten genera, including Elymus sensu stricto (Elymus s.s.) (StH), Roegneria C.Koch (StY), Hystrix Moench (StH/NsXm), Stenostachys Turcz. (HW), Douglasdeweya C.Yen, J.L.Yang et B.R.Baum (StP), Kengyilia C.Yen et J.L.Yang (StYP), Campeiostachys Drobov (StYH), Anthosachne Steudel (StYW), Pascopyrum Á. Löve (StHNsXm), and Connorochloa Barkworth, S.W.L.Jacobs et H.Q.Zhang (StYWH) [5-8, 13-16]. Of which, due to the dominant effect of the genes of the $\mathbf{S t}$ and $\mathbf{H}$ genomes, it is challenging to distinguish Campeiostachys from Elymus s.s. based on single or combined morphological characters $[6,8,17]$. Moreover, the genome composition of many polyploid species in Elymus s.s. and Campeiostachys is still unknown, resulting in the classification of many species in these two genera remains controversial $[6,8]$. Although the genome composition of some species is determined, their biosystematics remains controversial due to their similar morphological features.

Elymus breviaristatus (Keng) Keng ex Keng f. and Elymus sinosubmuticus S. L. Chen is sympatric species mainly distributed on hillsides in Sichuan, Qinghai, and Ningxia, China [9, 18-21]. Morphologically, those two species are quite similar, and the only difference exists in their awn length. E. breviaristatus has short awn (2-5 mm), while E. sinosubmuticus possesses degenerated awn only $0-2 \mathrm{~mm}$ in length $[9,19,22]$. Overlapping geographical distribution and similar morphology, whether or not they are the same species is under controversy. Based on the morphological characteristics and the results of RPDA analysis, these two species were treated as independent biological species $[8,9,19$, 21, 23]. Zhang et al. [24] suggested that E. breviaristatus and E. sinosubmuticus were the same species by comparing the leaf anatomical characteristics.

The chromosome pairing behavior of hybrid $F_{1}$ at meiosis metaphase can be used to indicate chromosome homology and evolutionary relationship between genus or species in Triticeae [25, 26]. Genomic in situ hybridization (GISH) can effectively examine the genome composition and chromosomal rearrangement of polyploid species [27-32]. Cytologically, E. breviaristatus and E. sinosubmuticus are allohexaploid $(2 \mathrm{n}=6 \mathrm{x}=42)$ perennial wheatgrass $[1,8,21,33]$, but Mason-Gamer et al. [34] reported that E. breviaristatus is tetraploid with StH genome. Based on the genome analysis and GISH, Yang et al. [35] recognized that E. breviaristatus was a hexaploid with the StYH genome and treated it as Campeistachys breviaristata (Keng) Y.H.Zhou, H.Q.Zhang et C.R.Yang. However, the genome composition of E. sinosubmuticus has not been reported at present.

Cytological and phylogenetic analyses are practical tools to determine the genome composition and explore the interspecies and intergeneric relationships of the species in Triticeae [36-39]. Molecular phylogeny analysis based on the single- or low-copy nuclear genes is less susceptible to concerted evolution and can be a handy marker for polyploid phylogeny [40-44]. Furthermore, Petersen et al. [43] found a correspondence between DNA sequences of diploid donors and allopolyploids in Triticeae. Therefore, more and more single-copy nuclear genes have been used to determine the genome composition and phylogenetic relationship of Triticeae. Acc1 and $D M C 1$ sequences have higher evolutionary rates and have been widely applied in the phylogenetic study of the genera of Triticeae, such as Triticum, Kengyilia, Leymus, Roegneria, Hystrix, etc. [44-49]. In the present study, GISH, single-copy nuclear genes, and artificial hybridization were used to investigate the genome composition of E. sinosubmuticus and explore the biosystematics relationships between $E$. breviaristatus and $E$. sinosubmuticus.

\section{Results}

\section{Meiosis and fertility of parentals and $F_{1}$ hybrids}

Five hybrids were obtained from the combination of $E$. breviaristatus $\times E$. sinosubmuticus. We observed the chromosome pairing of PMCs at metaphase I (MI) of parents and hybrids (Table 1). Meiosis of E. breviaristatus and E. sinosubmuticus forming mostly ring bivalents, with an average of 21.00 and 20.92 bivalents per cell, respectively (Table 1; Fig. S1, see Additional file 1). The $\mathrm{F}_{1}$ hybrids of $E$. breviaristatus $\times E$. sinosubmuticus was a hexaploid $(2 \mathrm{n}=42)$, showing an average of 0.50 univalents, 20.62 bivalents, 0.06 trivalent, and 0.02 quadrivalents (Table 1; Fig. S1, see Additional file 1). The chiasmata per cell were 37.70 , with a c-value of 0.89 , suggesting that they were genetically affinity species and had similar StYH genome constitution.

Pollen grains of parents (E. breviaristatus and E. sinosubmuticus) showed a high level of stainability, was $92.91 \%$ and $92.32 \%$, respectively. The percentage of stained pollen grains of the hybrids was comparatively high at $53.90 \%$. The seed setting rate of E. breviaristatus and E. sinosubmuticus were $89 \%$ and $87 \%$, respectively. And the seed setting rate of their hybrids was $22.46 \%$, indicating that the two species were highly affinities.

\section{GISH analysis}

To confirm the genome constitution of E. sinosubmuticus, root meristem cells that went through mitosis metaphase were collected for GISH. It showed that $E$. 
Table 1 Meiotic associations at metaphase I in pollen mother cells of parental species and their hybrids

\begin{tabular}{|c|c|c|c|c|c|c|c|c|c|c|}
\hline \multirow[t]{2}{*}{ Species or hybrids } & \multirow[t]{2}{*}{$2 n$} & \multirow{2}{*}{$\begin{array}{l}\text { No. of cells } \\
\text { observed }\end{array}$} & \multicolumn{6}{|c|}{ Chromosome association } & \multirow[t]{2}{*}{ Chiasmata/cell } & \multirow[t]{2}{*}{ c-value } \\
\hline & & & 1 & II (Total) & II (Ring) & II (Rod) & III & IV & & \\
\hline \multirow[t]{2}{*}{ Elymus breviaristatus } & 42 & 50 & - & 21.00 & 20.74 & 0.26 & - & - & 41.74 & 0.99 \\
\hline & & & - & $(21)$ & $(19-21)$ & $(0-2)$ & - & - & & \\
\hline \multirow[t]{2}{*}{ Elymus sinosubmuticus } & 42 & 50 & 0.08 & 20.92 & 20.72 & 0.20 & - & - & 41.64 & 0.99 \\
\hline & & & $(0-2)$ & $(20-21)$ & $(19-21)$ & $(0-2)$ & - & - & & \\
\hline \multirow[t]{2}{*}{ E. breviaristatus $\times$ E. sinosubmuticus } & 42 & 50 & 0.50 & 20.62 & 16.88 & 3.74 & 0.06 & 0.02 & 37.70 & 0.89 \\
\hline & & & $(0-2)$ & $(19-21)$ & $(13-19)$ & $(1-8)$ & $(0-1)$ & $(0-1)$ & & \\
\hline
\end{tabular}

sinosubmuticus is a hexaploid with 42 chromosomes. Of which, 28 chromosomes were hybridized with the StY probe (from Roegneria ciliaris (Trin.) Nevski) when blocked by the $\mathbf{H}$ genome (from Hordeum bogdanii Wilensky) (Fig. 1a). And 14 chromosomes were hybridized with the $\mathbf{H}$ probe when blocked by the $\mathbf{S t Y}$ genome (Fig. 1b). Double-color GISH showed that 28 chromosomes were stained by the StY probe (in red), and 14 chromosomes were labeled by the $\mathbf{H}$ probe (in green) (Fig. 1c). In accordance, E. breviaristatus also contains 42 chromosomes, and 28 chromosomes displayed StY signals on the entire arm, and 14 chromosomes showed H signals (Fig. 1d, e, f).

\section{Phylogenetic analyses}

The Acetyl-CoA carboxylase (Acc1) sequences length of E. sinosubmuticus ranged from 1421 to $1443 \mathrm{bp}$, and $E$. breviaristatus went from 1428 to $1441 \mathrm{bp}$. The Acc1 data matrix of sequences was analyzed based on maximum likelihood (ML) using the model TIM1 + I+G (-Ln likelihood $=8147.4309$ ). The assumed nucleotide frequencies were $\mathrm{A}=0.2555, \mathrm{C}=0.1794, \mathrm{G}=0.2116, \mathrm{~T}=0.3535$. The
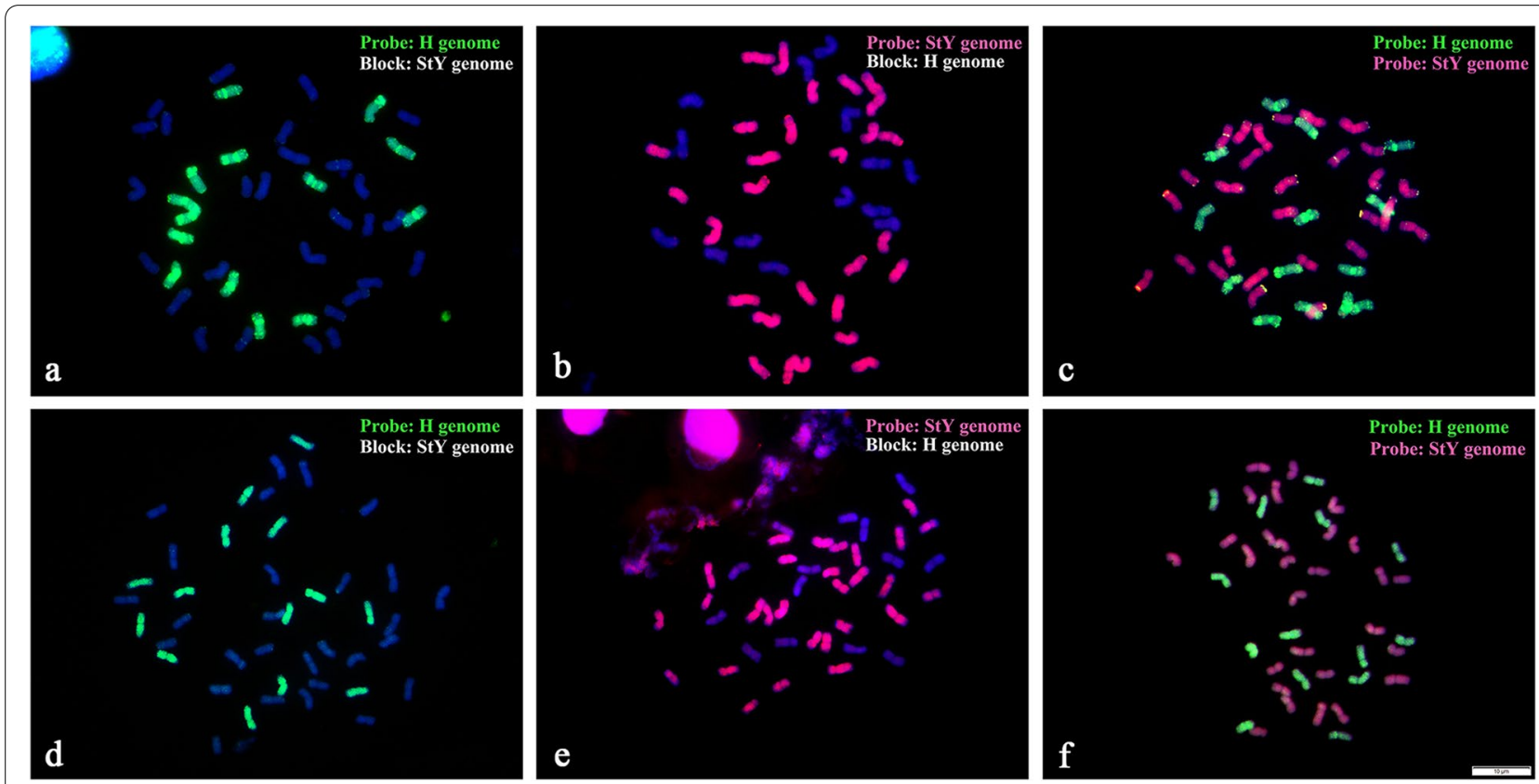

Fig. 1 GISH on somatic metaphase cells from root tips of Elymus sinosubmuticus and Elymus breviaristatus. a-c, E. sinosubmuticus. a, 14 chromosomes showed $\mathbf{H}$ genome single which from Hordeum bogdanii when blocked with StY genome which from Roegneria ciliaris. $\mathbf{b}, 28$ chromosomes showed $\mathbf{S t} \mathbf{Y}$ singles when blocked with $\mathbf{H}$ genome. $\mathbf{c}, 14$ chromosomes showed $\mathbf{H}$ genome singles and 28 chromosomes showed StY singles when StY genome and $\mathbf{H}$ genome as probes. $\mathbf{d}-\mathbf{f}$, E. breviaristatus. $\mathbf{d}, 14$ chromosomes showed $\mathbf{H}$ genome singles when blocked with StY genome. e, 28 chromosomes showed $\mathbf{S t} \mathbf{Y}$ singles when blocked with $\mathbf{H}$ genome. $\mathbf{f}, 14$ chromosomes showed $\mathbf{H}$ genome singles and 28 chromosomes showed $\mathbf{S t} \mathbf{Y}$ singles when $\mathbf{S t} \mathbf{Y}$ genome and $\mathbf{H}$ genome as probes. Scale bar equal $10 \mu \mathrm{m}$ 
tree generated by Bayesian analysis was similar to ML analysis. All the Acc1 sequences were grouped into six clades (Fig. 2). The sequence from E. breviaristatus and E. sinosubmuticus were divided into clade I, clade III, and clade IV, respectively. Clade I contained the Pseudoroegneria,
Elymus, Roegneria, and Campeiostachys species (BS $=100 \%$, $\mathrm{PP}=76 \%$,). Clade III included in the Dasypyrum, Roegneria, and Campeiostachys species ( $\mathrm{BS}=100 \%, \mathrm{PP}=80 \%$,). Clade IV grouped with the Hordeum, Elymus, and Campeiostachys species $(\mathrm{BS}=100 \%, \mathrm{PP}=100 \%)$.

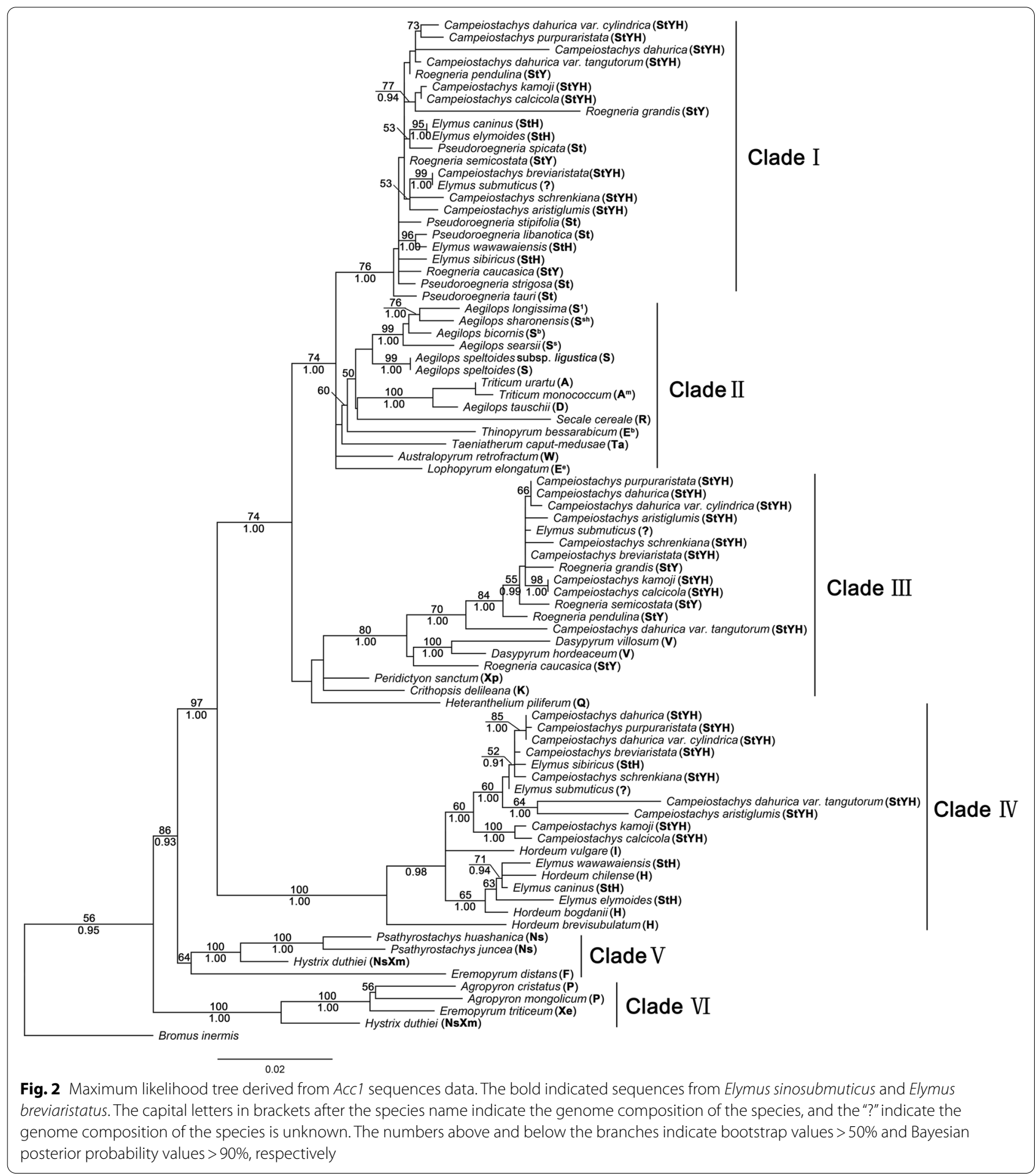


A total of 71 disrupted meiotic cDNA (DMC1) sequences were used for ML analysis, Bromus sterilis as the outgroup. TPM2uf $+\mathrm{G}$ as the best-fit model, -Ln likelihood $=5355.5355$. The assumed nucleotide frequencies were $A=0.2576, C=0.2120, G=0.2085, T=0.3220$. The tree generated by Bayesian analysis was similar to $\mathrm{ML}$ analysis. The $D M C 1$ sequences from $E$. breviaristatus and E. sinosubmuticus were divided into three clades (Fig. 3). In clade I, grouped with the diploid species (Pseudoroegneria), and tetraploid species (Elymus and Roegneria), and hexaploid species (Campeiostachys) ( $\mathrm{BS}=97 \%$; $\mathrm{PP}=74 \%$ ). In clade II, their sequences grouped with the species of the genus Roegneria and Campeiostachys $(\mathrm{BS}=99 \%, \mathrm{PP}=70 \%)$. In clade III, grouped with the diploid species (Hordeum) and the species of the genus Elymus and Campeiostachys ( $\mathrm{BS}=100 \%, \mathrm{PP}=59 \%)$. Clade IV and clade $\mathrm{V}$ grouped with the other diploid species in Triticeae (Fig. 3).

\section{Discussion}

\section{Elymus sinosubmuticus contains StStYYHH genome}

In this study, genome analysis, GISH, and phylogenetic analyses indicate that E. sinosubmuticus is an allohexaploid with the StYH genome. Based on the genome combinations, the species with $\mathbf{S t}, \mathbf{Y}, \mathbf{H}$ genomes should be classified into the genus of Campeiostachys [6]. Previously, E. sinosubmuticus was classified into the Elymus genus based on morphological traits and geographic distribution $[8,9,21]$. Phenotype is the co-consequence of genetics and environments. Some studies have shown that there are cryptic species (such as Roegneria panormitana (Parl.) Nevski and $R$. heterophylla (Bornm. ex Melderis) C. Yen, J. L. Yang and B. R. Baum) and cryptic genera (such as Elymus and Campeiostachys) in Triticeae $[6,8,50]$. The former has complete reproductive isolation, and the latter has different genome combinations. None of them can be distinguished morphologically. Therefore, for the Triticeae, especially for cryptic genera, it is not accurate to classify the species based only on morphological traits. Our study is reasonable to classify E. sinosubmuticus into the genus Campeiostachys based on the genome analysis, GISH, and phylogenetic analyses results.

\section{Biosystematics relationships of $E$. breviaristatus and $E$. sinosubmuticus}

There is still debate whether or not E. breviaristatus and E. sinosubmuticus are the same species [8, 23]. Karyotype analysis showed that those two hexaploid species belonged to type 2A [20]. From the leaf anatomical structure, the comparison of the leaf anatomical characteristics showed that the external morphology of $E$. breviaristatus and E. sinosubmuticus had little difference in leaf anatomy, and it was difficult to distinguish. Therefore, E. breviaristatus and E. sinosubmuticus were the same species, and E. sinosubmuticus should be a synonym for E. breviaristatus [24]. Conversely, Zhou et al. [23] based on the results of RPDA analysis, despite the close relationship between them, there was a certain degree of nucleotide sequence difference, and they were independent biological species. The morphological characteristics of E. breviaristatus and E. sinosubmuticus we observed were differing little. Both species are perennial tufted plants, culms erect. Leaf-sheaths glabrous, leafblades flat, margins ciliate. Spikes nodding or curved, with sparse remote spikelets, two spikelets on each rachis node, green or purple-tinged. Lemma is lanceolate and with five nerves. Palea is equal to lemma. Anthers yellow. The most significant difference is the length of the lemma awn, E. sinosubmuticus is only $0-2 \mathrm{~mm}$, and E. breviaristatus is $2-6 \mathrm{~mm}$. In addition, many types of interspecific variations were found in our field studies.

A high chromosome pairing frequency of hybrid $F_{1}$ can indicate that the parents are closely related [51, 52]. A species represents an independent gene pool in the evolutionary system, and reproductive isolation is the only factor for forming such independent gene pools in organismal evolution [15]. Accordingly, reproductive isolation is the only standard for species identification. In our study, the hybrid $\mathrm{F}_{1}$ of E. breviaristatus and E. sinosubmuticus has a high-frequency bivalent at MI (mean value of 20.62), suggesting that the three genomes of $E$. breviaristatus and E. sinosubmuticus has high homology, and they are closely related. But the percentage of stained pollen grains of hybrids was $53.90 \%$, and the seed setting rate was $22.46 \%$. This suggests genetic differentiation between the two taxa, leading to a degree of reproductive isolation. Yang et al. [35] reported that E. breviaristatus was a hexaploid with the StYH genome and treated it as Campeiostachys breviaristata (Keng) Y. H. Zhou, H. Q. Zhang et C. R. Yang. Combined with morphological characteristics and the fertility of hybrids, E. sinosubmuticus should be classified into the genus Campeiostachys as the subspecies of E. breviaristatus and renominated as Campeiostachys breviaristata (Keng) Y. H. Zhou, H. Q. Zhang et C. R. Yang subsp. sinosubmuticus (S. L. Chen) Y. H. Zhou, H. Q. Zhang et L. Tan.

\section{Conclusions}

Elymus sinosubmuticus is allohexaploid wheatgrass, and the genome composition is StYH. Its morphological characteristics are very similar to E. breviaristatus. Simultaneously, E. sinosubmuticus and E. breviaristatus have a degree of reproductive isolation, and it is reasonable to treat E. sinosubmuticus as the subspecies of $E$. breviaristatus. Because E. breviaristatus was treated as 


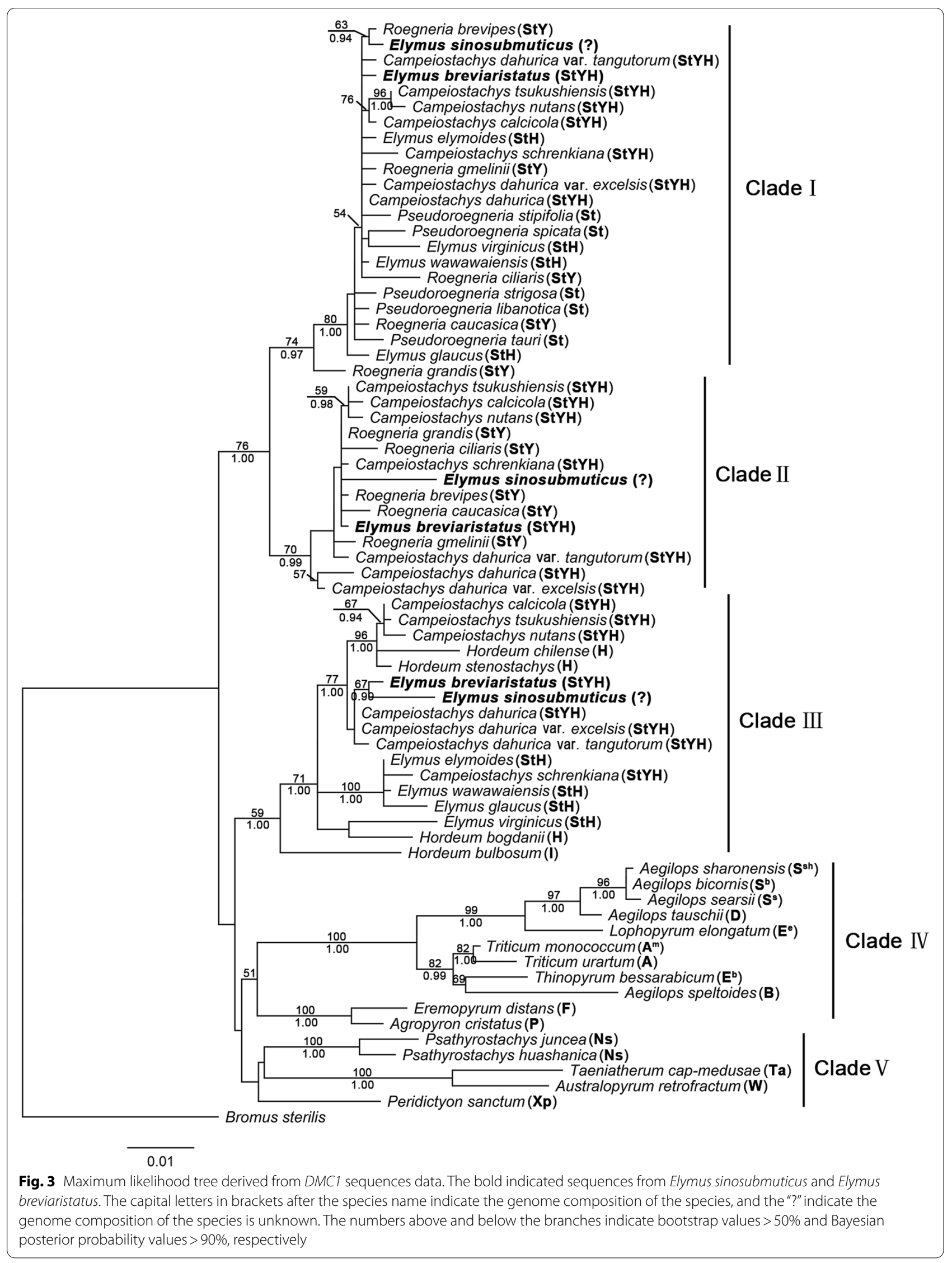


Campeiostachys breviaristata by Yang et al. [35], therefore, E. sinosubmuticus should be renamed as Campeiostachys breviaristata (Keng) Y. H. Zhou, H. Q. Zhang et C. R. Yang subsp. sinosubmuticus (S. L. Chen) Y. H. Zhou, H. Q. Zhang et L. Tan.

\section{Methods}

\section{Plant materials}

In our study, Elymus breviaristatus and Elymus sinosubmuticus were collected from the field in Sichuan Province, China, and numbered ZY 17,004 and ZY 17,008 respectively. No permissions were necessary to collect seed samples. Yonghong Zhou and Haiqin Zhang identified the two plant materials. They were used for artificial hybridization, and the materials and $\mathrm{F}_{1}$ hybrids were cultivated in the greenhouse at Hongyuan, Sichuan. The voucher specimens of E. breviaristatus and E. sinosubmuticus were deposited in the Herbarium of Triticeae Research Institute of Sichuan Agricultural University, China (SAUTI). Apart from E. breviaristatus and E. sinosubmuticus, diploid species and relative polyploid species with different genome combinations (StY, StH, StYH) in Triticeae were also applied for phylogenetic analyses. The basic information about these sequences is listed in Additional file 2: Table S1.

\section{Hybridization and meiotic analysis}

The hybridization procedure is as follows: after 2-3 days of the emasculation of the female parent, repeat pollinations with the corresponding mature pollens of the male parent were carried out. The female parents were used a plastic bag to isolate the pollen throughout the whole process. In crossing combination, E. breviaristatus was used as the male parent when crossed with $E$. sinosubmuticus, and E. sinosubmuticus was used as the male when hybridized with $E$. breviaristatus. The chromosome pairing of pollen grains of hybrids and parents was examined after fixing by Carnoy's Fluid II for $24 \mathrm{~h}$. The mean pairing frequency of hybrids and parents at MI is described by Kimber and Alonso [53]. Mature pollen of hybrids and parents were detected activity after staining with $\mathrm{I}_{2}$-IK solution.

\section{Chromosome preparation and GISH}

The roots were collected from adult plants, treated with nitrous oxide for three hours, fixed with $90 \%$ glacial acetic acid for $5 \mathrm{~min}$, and kept with $70 \%$ alcohol. The chromosome was prepared by drop methods [54]. Using the CTAB method [55] extracted the total genomic DNA from leaves. DNA was labeled using DIG-Nick Translation Kit (Roche, Indianapolis, IN, USA). The green probes were labeled with fluorescein-12-dUTP, and the red probes were labeled with Texas-red-5-dCTP using the nick translation method. Hybridization procedure, detection, and visualization are referred to Han et al. [56]. For monochromatic GISH, the concentration ratio of probe genomic DNA and non-labeled blocking genomic DNA was 1:120 (ng/uL). For double-color GISH, the concentration ratio of probes was 1:1 (ng/uL). Images of GISH were captured by Olympus BX61 fluorescence microscopy (Japan). At least ten metaphase cells for each species were observed. Adobe Photoshop CS6 was used to proceed with the images.

\section{Sequence amplification and phylogenetic analyses}

The Acc1 and DMC1 sequences were amplified with primers listed in Table 2 . All polymerase chain reactions were amplified in a $50 \mathrm{uL}$ reaction mixture, containing 25 uL $1 \times$ phanta mix buffer, $1 \mathrm{mM}$ dNTP mix, 1 uL DNA polymerase (Vazyme, Nanjing, China), $10 \mathrm{uM}$ of each primer, $200 \mathrm{ng}$ of template DNA, and distilled deionized water to the final volume. Polymerase chain reaction (PCR) products were cloned into the 007VS vector (TSINGKE Biological Technology, Beijing, China). At least 15 random independent clones were selected for sequencing by Sangon Biological Engineering and Technology Service Ltd. (Shanghai, China). DNA sequences were confirmed through BLAST nucleotide alignment on NCBI database. The multiple sequences were aligned, and manual adjustments were made using the ClustalX [57]. jModelTest 3.0 [58] was used to determine appropriate DNA substitution models and gamma rate heterogeneity. Phylogenetic analyses were conducted using the maximum-likelihood method in PhyML 3.0 [59] and Bayesian inference (BI) in MrBayes version 3.1.2 [60]. Statistical support for nodes in ML analysis was estimated by using 1000 fast bootstrap replicates. Bootstrap support (BS) value $<50 \%$ and posterior probabilities (PP) value $<90 \%$ was not included in figures.

Table 2 The primers used in this study

\begin{tabular}{|c|c|c|c|}
\hline Gene & Name of primer & Sequence of primer $\left(5^{\prime}-3^{\prime}\right)$ & Profiles \\
\hline \multirow[t]{2}{*}{ Acc1 } & AccF1 & $\begin{array}{l}\text { CCCAATATTTATCATGAGACT } \\
\text { TGCA }\end{array}$ & \multirow{2}{*}{$\begin{array}{l}1 \text { cycle: } 5 \text { min } \\
95^{\circ} \mathrm{C} \text {; } \\
35 \text { cycles: } 30 \mathrm{~s} \\
95^{\circ} \mathrm{C}, 30 \mathrm{~s} 56^{\circ} \mathrm{C} \\
2 \mathrm{~min} 30 \mathrm{~s} 68^{\circ} \mathrm{C} \text {; } \\
1 \text { cycle: } 10 \mathrm{~min} \\
68^{\circ} \mathrm{C}\end{array}$} \\
\hline & AccF2 & $\begin{array}{l}\text { CAACATTTGAATGAAThCTC } \\
\text { CACG }\end{array}$ & \\
\hline \multirow[t]{2}{*}{ DMC1 } & TDMCle10F & $\begin{array}{l}\text { TGCCAATTGCTGAGAGAT } \\
\text { TTG }\end{array}$ & \multirow{2}{*}{$\begin{array}{l}1 \mathrm{cycle:} 4 \mathrm{~min} \\
95^{\circ} \mathrm{C} \text {; } \\
35 \text { cycles: } \\
1 \text { min } 95^{\circ} \mathrm{C} \text {, } \\
1 \text { min } 52^{\circ} \mathrm{C} \\
1 \text { min } 72^{\circ} \mathrm{C} ; \\
1 \text { cycle: } 10 \text { min } \\
72^{\circ} \mathrm{C}\end{array}$} \\
\hline & TDMC1e15R & AGCCACCTGTTGTAATCTGG & \\
\hline
\end{tabular}




\section{Abbreviations}

Acc1: Acetyl-CoA carboxylase;" BS: Bootstrap support;" BI: Bayesian inference; DMC1: Disrupted meiotic cDNA “; GISH: Genomic in situ hybridization;" MI: Metaphase l; ML: Maximum likelihood;: PCR: Polymerase chain reaction;" PP: Posterior probability.

\section{Supplementary Information}

The online version contains supplementary material available at https://doi. org/10.1186/s12870-022-03441-y.

\section{Additional file 1.}

Additional file 2 .

\section{Acknowledgements}

We are thankful to Xiaoxia Zhu and Chenxi Hou from Sichuan Agricultural University for their help during artificial hybridization. And sincerely thanks to Xuehua Deng from Sichuan Academy of Grassland Science for her management of the experimental plants.

\section{Authors' contributions}

$\mathrm{ZYH}$ and $\mathrm{ZHQ}$ designed the study and revised the manuscript; TL carried out most of the experiments and data analyses and wrote the manuscript; HQX and SY carried out

parts of experiments and participated in the writing; WDD and CYR helped to draft the manuscript and participated in language editing; ZCB, SLN, and FX collected seed materials and participated in the data analyses; KHY and WY carried out the English modification and gave very important suggestions in the experiments; All authors read and approved the final manuscript.

\section{Funding}

This project was supported by the National Natural Science Foundation of China (Grant Nos. 31870309 and 31670331) and the Science and Technology Bureau of Sichuan Province (2021NZZJ0010).

\section{Availability of data and materials}

All sequences data from this study were deposited in National Center for Biotechnology Information (NCBI) and the accession number are MT749376, MT749377, MT749378, MT749380, MT749381, MT749382, MT820539, MT820540, MT820541, MT820545, MT820546, MT820549.

\section{Declarations}

Ethics approval and consent to participate

Not applicable.

\section{Consent for publication}

Not applicable.

\section{Competing interests}

The authors declare that they have no competing interests.

\section{Author details}

${ }^{1}$ Triticeae Research Institute, Sichuan Agricultural University, Wenjiang 611130, Chengdu, Sichuan, China. ${ }^{2}$ State Key Laboratory of Crop Genetic Exploration and Utilization in Southwest China, Sichuan Agricultural University, Wenjiang 611130, Chengdu, Sichuan, China. ${ }^{3}$ Sichuan Academy of Grassland Science, Chengdu 610000, Sichuan, China. ${ }^{4}$ College of Grassland Science and Technology, Sichuan Agricultural University, Chengdu 611130, Sichuan, China.

\section{Received: 29 September 2021 Accepted: 18 January 2022}

Published online: 01 February 2022

\section{References}

1. Löve Á. Conspectus of the Triticeae. Feddes Repert. 1984;95:425-521.

2. Yen C, Yang JL. Biosystematics of Triticeae, vol. 5. Beijing: China Agricultural Press; 2013. p. 1-216.
3. Dewey DR. The genome system of classification as a guide to intergeneric hybridization with the perennial Triticeae. In: Gustafson JP Gene manipulation in plant improvement. Plenum, New York, USA;1984. p. 209-79.

4. Yen C, Yang JL, Baum BR. Douglasdeweya, a new genus, with a new species and a new combination (Triticeae: Poaceae). Can J Bot. 2005;83:413-9.

5. Barkworth ME, Jacobs SWL, Zhang HQ. Connorochloa: a new genus in the Triticeae (Poaceae). Breed Sci. 2009;59:685-6.

6. Baum BR, Yang JL, Yen C, Agafonov AV. A taxonomic synopsis of the genus Campeiostachys Drobov. J Syst Evol. 2011;49:146-59.

7. Yen C, Yang JL. Biosystematics of Triticeae, vol. 3. Beijing: China Agricultural Press; 2011.

8. Yen C, Yang JL. Biosystematics of Triticeae, vol. 4. Beijing: China Agricultural Press; 2013.

9. Zhou YH. 2017. Flora Sichuanica. Chengdu: Sichuan Publishing House of Science and Technology; 2017. p. 277-403.

10. Baum BR, Yen C, Yang JL. Taxonomic separation of Kengyilia (Poaceae: Triticeae) in relation to nearest related Roegneria, Elymus, and Agropyron, based on some morphological characters. Plant Syst Evol. 1995:1995(194):123-32.

11. Zhang HQ, Zhou YH. Meiotic analysis of the interspecific and intergeneric hybrids between Hystrix patula Moench and H. duthiei ssp. Iongearistata, Pseudoroegneria, Elymus, Roegneria, and Psathyrostachys species (Poaceae, Triticeae). Bot J Linn Soc. 2007;153:213-9.

12. Dong ZZ, Fan X, Sha LN, Wang Y, Zeng J, Kang HY, Zhang HQ, Wang XL, Zhang L, Ding CB, Yang RW, Zhou YH. Phylogeny and differentiation of the St genome in Elymus L. sensu lato (Triticeae; Poaceae) based on one nuclear DNA and two chloroplast genes. BMC Plant Biol. 2015;15:179.

13. Yen C, Yang JL. Kengyilia gobicola, a new taxon from west China. Can J Bot. 1990;68:1894-7.

14. Cai LB. A taxonomical study on the genus Roegneria C. Koch from China Acta Phytotax Sin. 1997;35:148-77.

15. Yen C, Yang JL, Yen Y. Hitoshi Kihara, Áskell Löve and the modern genetic concept of the genera in the tribe Triticeae (Poaceae). Acta Phytotax Sin. 2005:43:82-93.

16. Yen C, Yang JL, Baum BR. Biosystematics of Triticeae. Beijing: China Agricultural Press; 2006. p. 3-18, 195-224.

17. Assadi M, Runemark H. Hybridization, genomic constitution and generic delimitation in Elymus s.l. (Poaceae: Triticeae). Plant Syst Evol. 1995;194:189-205.

18. Keng YL. Flora illustralis plantarum primarum sinicarum, Gramineae. Beijing: Science Press; 1959. p. 342-99.

19. Kuo PC. Flora reipublicae popularis sinicae. Beijing: Science Press; 1987.

20. Cai LB, Feng HS. Study on karyotypes of 3 species of Elymus. Acta Bot Boreal-Occident Sin. 1997;17:238-41.

21. Chen SL, Zhu GH. Tribus Triticeae, Poaceae. In: Wu ZY, Raven PH, Hong DY, editors. Flora of China. Beijing: Science Press; 2006. p. 386-444.

22. Gu XY, Guo ZH, Zhang XQ, Zhou K, Zhou CJ, Fu KX, Liu X, Ma X. Phenotypic variations in seven ex-situ conservation populations of Elymus breviaristatus. Acta Pratacul Sin. 2015;24:141-52.

23. Zhou YH, Zhen YL, Yang JL, Yen C, Jia JZ. Phylogenetic relationships among ten Elymus species based on random amplified polymorphic DNA. Acta Phytotax Sin. 1999:37:425-32.

24. Zhang TL, Su X, Cai LB. Reduction on Elymus sinosubmuticus based on the external morphology and micromorphological characteristics of leaf blades. Acta Bot Boreal-Occident Sin. 2008;28:1333-8.

25. Kihara H. Genome analysis of Triticum and Aegilops. Cytologia. 1930;1:263-70

26. Sakamoto S. Cytogenetical studies on artificial hybrids among Elymus sibiricus, E. dahuricus and Agropyron tsukushiense in the tribe Triticeae, Gramineae. Bot Magaz. 1982;95:375-83.

27. Ørgaad M, Heslop-Harrison JS. Investigation of genome relationships between Leymus, Psathyrostachys and Hordeum inferred from genomic DNA: DNA in situ hybridization. Ann Bot. 1994;73:195-203.

28. Li CB, Zhang DM, Ge S, Lu BR, Hong DY. Identification of genome constitution of Oryza malampuzhaensis, O. minuta, and O. punctata by multicolor genomic in situ hybridization. Theor Appl Genet. 2001;103:204-11.

29. Yu HQ, Zhang C, Ding CB, Zhang HQ, Zhou YH. Genome constitutions of Roegneria alashanica, R. elytrigioides, R. magnicaespes and R. grandis (Poaceae: Triticeae) via genomic in-situ hybridization. Nord J Bot. 2010:28:1-6. 
30. Dou QW, Zhang TL, Tsujimoto H. Physical mapping of repetitive sequences and genome analysis in six Elymus species by in situ hybridization. J Syst Evol. 2011:49:347-52.

31. Wang QX, Han HM, Gao AN, Yang XM, Li LH. P chromosomes involved in intergenomic rearrangements of Kengyilia thoroldiana affected by the environment. J Genet. 2014;93:199-202.

32. Yang $C R$, Zhang $H Q$, Chen $W H$, Kang HY, Wang $Y$, Sha LN, Fan $X$, Zeng J, Zhou YH. Genomic constitution and intergenomic translocations in the Elymus dahuricus complex revealed by multicolor GISH. Genome. 2017;60:510-7.

33. Lu BR, Yan J, Yang JL. Cytological observations on Triticeae materials from Xinjiang. Qinghai and Sichuan Acta Bot Yunnan. 1990;12:57-66.

34. Mason-Gamer RJ, Burns MM, Naum M. Polyploidy, introgression, and complex phylogenetic patterns within Elymus. Czech J Genet Plant. 2005;41:21-6.

35. Yang CR, Baum BR, Chen WH, Zhang HQ, Liu XY, Fan X, Sha NL, Kang HY, Wang Y, Zhou YH. Genomic constitution and taxonomy of the Chinese hexaploids Elymus cylindricus and E. breviaristatus (Poaceae: Triticeae). Bot J Linn Soc. 2016;182:650-7.

36 Sakamoto S, Muramatsu M. Cytogenetic studies in the tribe Triticeae II Tetraploid and hexaploid hybrids of Agropyron. Jap J Genet. 1966;41:155-68.

37. Liu QL, Ge S, Tang HB, Zhang XL, Zhu GF, Lu BR. Phylogenetic relationships in Elymus (Triticeae, Poaceae) based on the nuclear ribosomal internal transcribed spacer and chloroplast $\operatorname{trn} L-F$ sequences. New Phytol. 2006;170:411-20.

38. Fan $X$, Sha LN, Dong ZZ, Zhang HQ, Kang HY, Wang Y, Wang XL, Zhang $L$, Ding $C B$, Yang RW, Zheng YL, Zhou YH. Phylogenetic relationships and $Y$ genome origin in Elymus sensu lato (Triticeae; Poaceae) based on single-copy nuclear Accl and Pgk1 gene sequences. Mol Phylogenet Evol. 2013;69:919-28.

39. Wang $L$, Jiang $Y Y$, Shi $Q H$, Wang $Y$, Sha LN, Fan $X$, Kang HY, Zhang $H Q$, Sun $\mathrm{GL}$, Zhang L, Zhou YH. Genome constitution and evolution of Elytrigia lolioides inferred from Acc1, EF-G, ITS, TrnL-F sequences and GISH. BMC Plant Biol. 2019;19:158.

40. Soltis DE, Soltis PS, Tate JA. Advances in the study of polyploidy since plant speciation. New Phytol. 2003;161:173-91.

41. Rauscher JT, Doyle JJ, Brown AH. Multiple origins and nrDNA internal transcribed spacer homoeologue evolution in the Glycine tomentella (Leguminosae) allopolyploid complex. Genetics. 2004;166:987-98.

42. Johnson LA, Johnson RL. Morphological delimitation and molecular evidence for allopolyploidy in Collomia wilkenii (Polemoniaceae), a new species from northern Nevada. Syst Bot. 2006;31:349-60.

43. Petersen G, Seberg O, Yde M, Berthelsen K. Phylogenetic relationships of Triticum and Aegilops and evidence for the origin of the A, B and D genomes of common wheat (Triticum aestivum). Mol Phylogenet Evol. 2006:39:70-82.

44. Sha LN, Fan X, Yang RW, Kang HY, Ding CB, Zhang L, Zheng YL, Zhou YH. Phylogenetic relationships between Hystrix and its closely related genera (Triticeae; Poaceae) based on nuclear Acc1, DMC1 and chloroplast trnL-F sequences. Mol Phylogenet Evol. 2010;54:327-35.

45. Huang SX, Sirikhachornkit A, Faris JD, Su XJ, Gill BS, Haselkorn R, Gornicki P. Phylogenetic analysis of the acetyl-CoA carboxylase and 3-phosphoglycerate kinase loci in wheat and other grasses. Plant Mol Biol. 2002:48:805-20.

46. Petersen G, Seberg O. Molecular evolution and phylogenetic application of DMC1. Mol Phylogenet Evol. 2002;22:43-50.

47. Nasernakhaei F, Rahiminejad MR, Saeidi H, Tavassoli M. Phylogenetic relationships among the Iranian Triticum diploid gene pool as inferred from the loci Accl and Pgk1. Phytotaxa. 2015;201:111-21.

48. Gao G, Tang ZL, Deng JB, Guo XM, Wang Q, Zhang Y, Ding CB, Zhang L, Zhou YH, Yang RW. Phylogenetic relationships and $Y$ genome origin in Kengyilia (Triticeae: Poaceae) based on single copy gene DMC1. Biologia. 2016;71:298-304.

49. Tang C, Qi J, Chen N, Sha LN, Wang Y, Zeng J, Kang HY, Zhang HQ, Zhou $\mathrm{YH}$, Fan X. Genome origin and phylogenetic relationships of Elymus villosus (Triticeae: Poaceae) based on single-copy nuclear Acc1, Pgk1, DMC1 and chloroplast trnL-F sequences. Bioch Syst Ecol. 2017;70:168-76.

50. Yen C, Yang JL, Baum BR. Roegneria heterophylla, a New Combination for Roegneria (Poaceae, Triticeae) from Lebanon. Novon J Bot Nomencl. 2008:18:405-7.
51. Lu BR, Liu JH. Genome analysis and biosystematics of the wheat tribe (Triticeae Dumort). Chin Bullet Bot. 1992;9:26-31.

52. Wang RRC. Genome relationships in the perennial Triticeae based on diploid hybrids and beyond. Hereditas. 1992;116:133-6.

53. Kimber G, Alonso LG. The analysis of meiosis in hybrids III Tetraploid hybrids. Can J Genet Cytol. 1981;1981(23):235-54.

54. Zhang HQ, Zhou YH. Meiotic pairing behaviour reveals differences in genomic constitution between Hystrix patula and other species of the genus Hystrix Moench (Poaceae, Triticeae). Plant Syst Evol. 2006;258:129-36

55. Doyle JJ, Doyle JL. Isolation of plant DNA from fresh tissue. Focus. 1990;12:13-5.

56. Han FP, Gao Z, Birchler JA. Reactivation of an inactive centromere reveals epigenetic and structural components for centromere specification in maize. Plant Cell. 2009;21:1929-39.

57. Thompson JD, Higgins DG, Gibson TJ. CLUSTAL W: improving the sensitivity of progressive multiple sequence alignment through sequence weighting positions-specific gap penalties and weight matrix choice. Nucl Acids Res. 1994;22:4673-80.

58. Posada D. jModelTest: phylogenetic model averaging. Mol Biol Evol. 2008;25:1253-6.

59. Guindon S, Delsuc F, Dufayard JF, Gascuel O. Estimating maximum likelihood phylogenies with PhyML. Methods Mol Biol. 2009;537:113-37.

60. Huelsenbeck JP, Ronquist F. MrBayes: Bayesian inference of phylogenetic trees. Bioinformatics. 2001;17:754-5.

\section{Publisher's Note}

Springer Nature remains neutral with regard to jurisdictional claims in published maps and institutional affiliations.
Ready to submit your research? Choose BMC and benefit from:

- fast, convenient online submission

- thorough peer review by experienced researchers in your field

- rapid publication on acceptance

- support for research data, including large and complex data types

- gold Open Access which fosters wider collaboration and increased citations

- maximum visibility for your research: over $100 \mathrm{M}$ website views per year

At BMC, research is always in progress.

Learn more biomedcentral.com/submissions 